\title{
Anti-collagen antibodies in sera from rheumatoid arthritis patients
}

\author{
HELEN K BEARD,* RUTH RYVAR,* J SKINGLE, $\dagger$ AND CL GREENBURY $\dagger$ \\ From the *Charles Salt Research Centre, Orthopaedic Hospital, Oswestry, Shropshire SY10 7AG and the \\ †Pathology Laboratory, Stoke Mandeville Hospital, Aylesbury, Bucks, UK
}

SUMMARY Anti-cartilage antibodies, demonstrable by immunofluorescence, were found in $3.3 \%$ of rheumatoid arthritis patients. In most of these patients antibodies to type II collagen were detected. In specificity studies on these anti-collagen antibodies, they appeared to be type specific, showing no reaction with collagen types I and III. Denatured type II collagen reacted much less well than native type II, but isolated peptides from different regions of the collagen molecule were differentiated by individual sera. Removal of the glycoside side chains from native type II collagen had no effect on its antigenicity. The findings suggest that these patients produce highly specific antibodies which react with the triple helix of type II collagen.

Collagen fibres are major constituents of all connective tissues where they provide mechanical strength. The fibres are built up of collagen molecules, which, in native form, have three polypeptide chains aligned in a rigid, rod-shaped structure with a triple helical conformation. ${ }^{1}$ In the last decade, more than fivedifferent types of collagen have been identified, ${ }^{2-5}$ which differ in their chemical composition, their tissue distribution, and their biological properties. ${ }^{6}$ ? Type II collagen has a particularly limited tissue distribution, occurring only in cartilage, intervertebral disc, and notochord. 289

The potential importance of collagen in connective tissue diseases, such as rheumatoid arthritis, has been pointed out more than once. ${ }^{10} 11$ It has been suggested that collagen may behave as an autoantigen in human patients, ${ }^{11}$ and, recently, a rat model of arthritis has been developed in which native type II collagen was shown to induce pathological changes in the joints. Other collagen types or denatured collagen did not have this capacity. ${ }^{12}$

A recent publication in this journal described the occurrence of anti-cartilage antibodies in patients with rheumatoid arthritis. ${ }^{13}$ These antibodies appeared in $3.3 \%$ of 1126 rheumatoid arthritis patients but were absent in 1825 blood donors and in patients with osteoarthrosis, ankylosing spondylosis, polymyalgia rheumatica, or gout. Antibodies to type II collagen were detected in most patients with

Received for publication 31 March 1980 anti-cartilage antibodies. In this paper additional studies on the specificity of these anti-collagen antibodies are described.

\section{Material and methods}

SOURCE OF SERA

All sera originated from patients with definite rheumatoid arthritis, as previously described. ${ }^{13}$

PREPARATION OF COLLAGEN FRACTIONS

1 Human types I and III collagens were prepared from a pepsin digest of placenta. 14

2 Human type II collagen was isolated from a pepsin digest of the nucleus pulposus of intervertebral disc. ${ }^{14}$ Chick type II collagen and its isolated cyanogen bromide peptides were prepared from sternal cartilage. ${ }^{15}$

3 Periodate treatment of collagen: Collagen $(1 \mathrm{mg} / \mathrm{ml})$ was dialysed against $0.05 \mathrm{M}$ sodium acetate, $\mathrm{pH} 4.5$, and potassium periodate was added to a final concentration of $30 \mathrm{mmol} / 1$. The mixture was stirred at $4^{\circ} \mathrm{C}$ for 48 hours and then dialysed against $0.5 \mathrm{M}$ acetic acid. The glucose content of these collagen preparations was assayed by glucose oxidase (Sigma Bulletin 510).

\section{HAEMAGGLUTINATION ASSAY}

Sheep red blood cells (Tissue Culture Services Ltd) were formolised, treated with tannic acid $(0.25 \mu \mathrm{g} / \mathrm{ml})$ in phosphate buffered saline, $\mathrm{pH} 7.2$ (PBS), and 
coated with human collagen according to the method of Das. ${ }^{16}$ The optimal coating concentration was in the range $50-500 \mu \mathrm{g} / \mathrm{ml}$.

Tests were performed in microtitre trays (Sterilin Ltd) using $25 \mu \mathrm{l}$ volumes with $0.4 \% \mathrm{v} / \mathrm{v}$ normal rabbit serum (preabsorbed with red blood cells and collagen) in PBS as diluent.

\section{HAEMAGGLUTINATION INHIBITION}

This was performed in two different ways.

1 Serum dilutions were made in microtitre trays, and $25 \mu \mathrm{l}$ of collagen $(200 \mu \mathrm{g} / \mathrm{ml})$ or collagen peptides $(10 \mathrm{mg} / \mathrm{ml})$ in PBS were added to each well. Control wells received PBS alone. The plate was then incubated at $4^{\circ} \mathrm{C}$ for 30 minutes. Sensitised sheep red blood cells were added, and allowed to settle, and the patterns were scored. The percentage inhibition was calculated as $\frac{2^{n-1} \times 100}{T}$, where $n=$ number of wells inhibited, and $T=$ titre of unhibited serum.

2 Periodate treatment of collagen resulted in some degree of aggregation, and the haemagglutination inhibition method was therefore modified for this experiment; $30 \mu \mathrm{l}$ of serum was mixed with $30 \mu \mathrm{l}$ of collagen in PBS $(1 \mathrm{mg} / \mathrm{ml})$ and incubated at $37^{\circ} \mathrm{C}$ for 30 minutes. The mixture was then centrifuged ( $1500 \mathrm{~g}$ for 10 minutes), and the supernatant was carefully removed and titrated against sensitised cells. In the control, PBS alone was added to the serum. The percentage inhibition was calculated as $100-\frac{100}{2^{n}}$, where $n=$ number of wells inhibited.

SOLID PHASE FLUORIMETRIC ASSAY This was kindly performed by Dr DJ Lea following methods previously described. 1417

\section{Results}

REACTION WITH HUMAN COLLAGEN TYPES I, II, AND III

A total of 37 patients with rheumatoid arthritis were found by immunofluorescence to have anti- cartilage antibodies in their serum, and in all but two of these, antibodies to type II collagen could be detected by haemagglutination, although in low titre in some cases. ${ }^{13}$

A number of these sera were tested against collagen types I, II, and III by haemagglutination, and, as shown in Table 1, all showed clear specificity for type II collagen. Weak reactions to type I collagen occurred in two cases. Three sera gave no reactions under these conditions (although positive
Table 1 Haemagglutination reactions with collagens types I, II, and III

\begin{tabular}{llrl}
\hline Patients & \multicolumn{2}{l}{ Native collagens } \\
\cline { 2 - 4 } & $I$ & $I I$ & III \\
\hline BE & 0 & 32 & 0 \\
BK & 0 & 16 & 0 \\
CD & 0 & 64 & 0 \\
CI. & 0 & 2048 & 0 \\
CM & 0 & 64 & 0 \\
CV & 0 & 1024 & 0 \\
ED & 0 & 4096 & 0 \\
FE & 0 & 256 & 0 \\
FH & 0 & 0 & 0 \\
HJ & 0 & 0 & 0 \\
KI & 0 & 2048 & 0 \\
LW & 0 & 256 & 0 \\
MJ & 0 & 128 & 0 \\
SA & 0 & 0 & 0 \\
SF & 4 & 32 & 0 \\
TC & 4 & 2048 & 0 \\
\hline
\end{tabular}

reactions had been obtained previously for two of them, $\mathrm{FH}$ and $\mathrm{HJ}$ ).

\section{ANTIBODY CLASS}

A number of these sera were also reacted with native type II collagen in a solid phase fluorimetric assay. Five sera (AA, BW, FC, KK, SA) gave very weak reactions in agreement with their haemagglutination titres $(10,<5,20,5,<5$, respectively) whereas two sera which were variable by haemagglutination (FH and $\mathrm{HJ}-$ see previous section) showed evidence of IgG binding in this assay. IgG binding to collagen was almost always higher than IgM binding (Figure), suggesting that the antibodie's were predominantly IgG class.

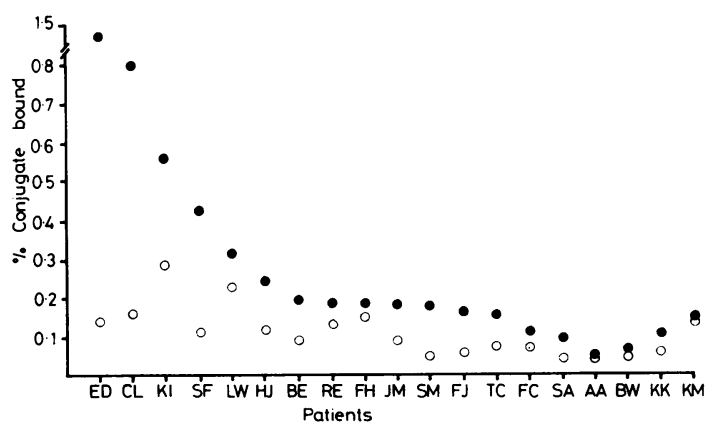

Solid phase fluorimetric assay: Comparison of $\operatorname{IgG}$ and IgM binding to native collagen by rheumatoid anticollagen antibodies. $\bigcirc \mathrm{IgM}$ ○ IgG.

REACTION WITH DENATURED TYPE II COLLAGEN

The ability of heat-denatured type II collagen $\left(50^{\circ} \mathrm{C}\right.$ for 30 minutes in $0.5 \mathrm{M}$ acetic acid) to inhibit 
the reaction of five sera with native type II collagen was tested by haemagglutination. As shown in Table 2, denatured type II collagen reacted with these antibodies in all cases, but much less strongly than the native collagen.

Table 2 Haemagglutination inhibition by denatured type II collagen

\begin{tabular}{lll}
\hline Patients & \multicolumn{2}{c}{ \% Inhibition by collagen } \\
\cline { 2 - 3 } & Native & Denatured \\
\hline CL & $>3 \cdot 1$ & $0 \cdot 4$ \\
ED & $>3 \cdot 1$ & $0 \cdot 2$ \\
LW & $>25$ & $3 \cdot 1$ \\
KI & $>25$ & $0 \cdot 8$ \\
TC & $>25$ & $6 \cdot 3$ \\
\hline
\end{tabular}

Values for native collagen are minima since inhibition was complete throughout the titrations.

Initial dilutions were 1/32 (CL, ED) and 1/4 (LW. KM, TC).

\section{REACTION WITH ISOLATED COLLAGEN}

PEPTIDES

The above findings indicated that the antigenic determinants were, to some degree, dependent on the native triple helical structure of collagen, this conformation being lost on heat denaturation. However, it appears that the structure of denatured collagen is sufficiently similar to native for it to retain a slight degree of antigenicity.

Collagen peptides isolated from different regions of chick type II collagen following cyanogen bromide digestion were available from previous work. ${ }^{15}$ Preparations contained CB8, CB10, or CB11, the large peptides from the centre of the collagen chain, and mixtures of $\mathrm{CB} 9+12$ and CB6 +7 , smaller peptides located near the carboxy and amino terminals. Since these peptides originated from different regions of the type II molecule and had different primary structures, it was decided to test their reactivity with anti-collagen antibodies.

Six sera were first tested for their ability to cross-react with denatured chick type II collagen. Three sera reacted poorly, and three reacted equally well with chick or human collagen. A similar heterogeneity was found among patients' sera when examined by immunofluorescence using rat and chick laryngeal cartilage. The latter three sera were then reacted with isolated chick type II peptides in haemagglutination inhibition, as shown in Table 3. Two of these sera were able to distinguish individual peptides, while the third reacted well with all the peptides tested.

\section{REACTION WITH PERIODATE-TREATED}

COLLAGEN

Type II collagen contains glycoside side chains attached $O$-glycosidically to hydroxylysine. It is possible to remove these groups by oxidation, so that their importance to collagen antigenicity can be assessed.

In this study, glycoside side chains were removed by periodate treatment, which was shown to reduce the glucose content of collagen from $0.5 \% \mathrm{w} / \mathrm{w}$ to less than $0.1 \% \mathrm{w} / \mathrm{w}$. This treatment had little effect on the ability of collagen to inhibit the haemagglutination reaction for five different human sera (Table 4). It would appear, therefore, that the sugar residues were irrelevant to antigenicity in these cases.

Table 3 Haemagglutination inhibition by collagen peptides

\begin{tabular}{lccccc}
\hline Patients & \multicolumn{5}{l}{$\%$ Inhibition by collagen peptides } \\
\cline { 2 - 6 } & $C B 10$ & $C B 11$ & $C B 8$ & $C B 9+12$ & $C B 6+7$ \\
\hline BE & 25 & $>50$ & $>50$ & NT & 25 \\
CL & 0 & 0 & 0.4 & $0 \cdot 1$ & $0 \cdot 1$ \\
TC & 3.9 & $>18$ & 2.0 & 0.1 & 0.2 \\
\hline
\end{tabular}

Figures are the means of two results in close agreement. Initial dilutions were $1 / 2$ (BE) and $1 / 4$ (CL, TC).

Table 4 Haemagglutination inhibition by periodatetreated collagen

\begin{tabular}{lll}
\hline Patient & \multicolumn{2}{l}{$\%$ Inhibition by collagen } \\
\cline { 2 - 3 } & Native & Native-periodate-treated \\
\hline CD & 91 & 91 \\
CL & 92 & 90 \\
CV & 97 & 94 \\
KI & 98 & 93 \\
TC & 98 & 98 \\
\hline
\end{tabular}

Figures are the means of two results in close agreement.

\section{Discussion}

We have demonstrated the presence of antibodies to type II collagen in most of the rheumatoid sera which showed anti-cartilage staining by immunofluorescence. Specificity studies on randomly selected sera showed that the anti-collagen antibodies were all specific for type II collagen and did not react with types I or III. All sera tested showed specificity for the native helical structure of collagen and reacted poorly with denatured collagen in which this conformation was lost as a result of gentle heating.

It seemed possible that antibodies in these rheumatoid sera may have reacted, not with native collagen itself, but with some other molecule which attached to collagen and formed an antigenic hapten. Such a hapten could link to collagen through the 
sugar residues. However, this idea was discounted in our study since removal of the sugar residues of collagen by periodate oxidation had no effect on its antigenicity.

Although all the sera tested showed consistent reactions with native or periodate-treated collagen, individual variations were observed in their reactions with chick cartilage (immunofluorescence), chick type II collagen, and its isolated cyanogen bromide peptides. Individual peptides reacted differently with three sera tested. Although this gives no information on the location of the antigenic determinants, which are clearly associated with the triple helix, it does indicate that these three sera had differing specificities. Similar subtle variations have been found among anti-collagen antisera raised in rabbits. ${ }^{18}$

The antibodies occurred in $3.3 \%$ of 1126 rheumatoid arthritis patients. ${ }^{13} 14$ Other workers have found a similar incidence among small groups of patients, for example, $2 / 47$ with anti-collagen ${ }^{19}$ and $1 / 35$ with anti-cartilage antibody. ${ }^{20}$ There have, however, been many reports of a much higher incidence of antibodies to collagen in rheumatoid arthritis patients. 11192122 In some cases nonantibody proteins, such as fibronectin, ${ }^{14}$ may have bound to denatured collagen, giving falsely positive results. When a high incidence of antibodies to native collagen has been found, 192123 all sera have reacted with more than one type of collagen. Since it has been shown that IgG bound native collagen through its $\mathrm{Fc}$ region, ${ }^{24}$ and human collagenase reacted with native collagen in haemagglutination, ${ }^{25}$ it is possible that some of these reactions may have been non-specific. In any case these type non-specific reactions are clearly distinct from the antibodies to native type II collagen which we have described.

There are no clinical means of distinguishing patients with anti-collagen antibodies from those without, although the incidence of antibodies is higher in patients with articular erosions. There is also an association with disease activity in so far as antibodies occur significantly more often in patients with a raised $\mathbf{C}$-reactive protein (unpublished data). The findings described here do not help in determining the role of anti-cartilage antibody, but it is interesting to speculate on why rheumatoid arthritis should give rise to an antibody directed at the intact molecule rather than at its breakdown products, a finding contrary to what might be expected of an antibody produced secondarily to tissue damage. The explanation may lie in a greater antigenicity of the native molecule in certain individuals. Experimental work in animals has shown that guinea-pigs, rats, and mice produce antibodies to native but not denatured collagen, whereas chicken and rabbits recognised both forms of collagen. 1526
There were a few anti-cartilage sera in which we could not demonstrate antibodies to collagen either by haemagglutination or by solid phase fluorimetry. There is thus a possibility that some at least of our sera contained antibodies to cartilage components other than collagen.

One of us (HKB) was supported by grant number G977/610 from the Medical Research Council. We thank Dr DJ Lea for performing the solid phase fluorimetric assay and for helpful discussions.

\section{References}

1 Traub W, Piez KA. Chemistry and structure of collagen. Adv Protein Chem 1971;25:243-352.

2 Miller EJ. Biochemical characteristics and biological significance of the genetically distinct collagens. Mol Cell Biochem 1976;13:165-92.

${ }^{3}$ Kefalides NA. Isolation of a collagen from basement membranes containing three identical $a$-chains. Biochem Biophys Res Commun 1971;45:226.

4 Burgeson RE, Hollister DW. Collagen heterogeneity in human cartilage: Identification of several new collagen chains. Biochem Biophys Res Commun 1976;87:1124-32.

${ }^{5}$ Burgeson RE, El Adli FA, Kaitila II, Hollister DW. Fetal membrane collagens: Identification of two new collagen alpha chains. Proc Natl Acad Sci 1976;73:2579-83.

- Trelstad RL, Carvalho ACA. Type IV and type 'A-B'C collagens do not elicit platelet aggregation or theo serotonin release reaction. J Lab Clin Med 1979;93:499505.

' Balleison L, Gay S, Marx R, Kuhn K. Comparative investigation on the influence of human and bovine collagen types I, II and III on the aggregation of human platelets. Klin Wochenschr 1975;53:903-5.

${ }^{8}$ Eyre DR, Muir $\mathrm{H}$. The distribution of different molecular species of collagen in fibrous, elastic and hyaline cartilages of the pig. Biochem $J$ 1975;151:595-602.

- Miller EJ, Matthews MB. Characterisation of notochord collagen as a cartilage-type collagen. Biochem Biophys Res Commun 1974;60:424-30.

${ }^{10}$ Klemperer P, Pollack AD, Baehr G. Diffuse collagen disease. Acute disseminated lupus erythematosus and diffuse scleroderma. JAMA 1942;119:331-2.

11 Steffen C. Tissue antibodies in rheumatoid arthritis and other connective tissue diseases. Ann Immunol 1969 1:47-58.

12 Trentham DE, Townes AS, Kang AH. Autoimmunity to type II collagen: An experimental model of arthritis. $J$ Exp Med 1977;146:857-68.

${ }^{13}$ Greenbury CL, Skingle J. Anti-cartilage antibody. $J$ Clin Pathol 1979;32:826-31.

14 Beard HK, Lea DJ, Ryvar R. Anomalous reactions in the haemagglutination assay for anti-collagen antibodies. Studies on patients with rheumatoid arthritis or chronic low back pain. J Immunol Methods 1979;31:119-28.

15 Beard HK, Udea M, Faulk WP, Glynn LE. Cell-mediated and humoral immunity to chick type II collagen and its cyanogen bromide peptides in guinea-pigs. Immunology 1978;34:323-35.

16 Das PC. Investigations and preparation of fibrinogencoated tanned sheep red cells. J Clin Pathol 1970;23:14955.

17 Lea DJ, Ward DJ. Estimation of IgM rheumatoid factors by fluorimetry. Ann Rheum Dis 1978;37:247-51. 
${ }^{18}$ Becker U, Fietzek PP, Furthmayr H, Timpl R. Nonhelical sequences of rabbit collagen. Correlations with antigenic determinants detected by rabbit antibodies in homologous regions of rat and calf collagen. Eur $J$ Biochem 1975;54:359-66.

19 Clague RB, Shaw MJ, Holt PJL. Incidence of serum antibodies to native type I and type II collagens in patients with inflammatory arthritis. Ann Rheum Dis 1980;39: 201-6.

${ }^{20}$ Foidart JM, Abe S, Martin GR et al. Antibodies to type II collagen in relapsing polychondritis. $N$ Engl $J$ Med 1978;299:1203-7.

21 Andriopoulos NA, Mestecky J, Miller EJ, Bradley EL. Antibodies to native and denatured collagens in sera of patients with rheumatoid arthritis. Arthritis Rheum 1976; 19:613-7.

22 Michaeli D, Fudenberg HH. The incidence and antigenic specificity of antibodies against denatured human collagen in rheumatoid arthritis. Clin Immunol Immuno- pathol 1974;2:153-9.

${ }^{23}$ Trentham DE, Dyresius RA, Rocklin RE, David JR. Cellular sensitivity to collagen in rheumatoid arthritis. $N$ Engl J Med 1978;299:327-32.

24 Eeckhout Y, Cambiaso CL, Riccomi H, Vaes G, Masson PL. Agglutination of IgG-coated particles by collagen. FEBS Lett 1979;107:69-72.

${ }^{25}$ Kojer M, Menzel EJ, Smolen JS, Zielinski C. Detection of collagenase in passive haemagglutination using collagencoated erythrocytes. Klin Wochenschr 1978;90:733-6.

${ }^{26}$ Beard HK, Faulk WP, Conochie LB, Glynn LE. Some immunological aspects of collagen. Prog Allergy 1977; 22:45-106.

Requests for reprints to: Dr Helen K Beard, Charles Salt Research Centre, Robert Jones \& Agnes Hunt Orthopaedic Hospital, Oswestry, Shropshire SY10 7AG, UK. 